Journal of Agricultural Sciences

Araştırma Makalesi (Research Article)

\title{
Evaluation of Land Use Suitability for Wheat Cultivation Considering Geo- Environmental Factors by Data Dependent Approaches
}

\author{
Onur ŞATIR* ${ }^{* 1}$, Süha BERBEROĞLU² \\ ${ }^{1}$ Van Yuzuncu Yil University Dept. of Landscape Architecture, 65090 Van, Turkey \\ ${ }^{2}$ Cukurova University Dept. of Landscape Architecture, 01330 Adana, Turkey \\ ${ }^{1} \mathrm{https} / / /$ orcid.org/0000-0002-0666-7784 ${ }^{2} \mathrm{https} / / /$ orcid.org/0000-0002-1547-6680 \\ *Corresponding author e-mail: osatir@yyu.edu.tr
}

\section{Article Info}

Recieved: 18.03.2021

Accepted: 02.06.2021

Online Published: 15.09.2021

DOI: 10.29133 /yyutbd. 898307

\section{Keywords}

Agricultural land use suitability,

Wheat,

Multi-criteria assessment, Artificial neural network, GIS.

\begin{abstract}
Two techniques were investigated to be standard deviation based weighting Multi Criteria Assessment (MCA), and Artificial Neural Network (ANN) considering base environmental factors to define wheat cultivation suitability in Van region. Climate data (long term annual, maximum and minimum temperature, total mean precipitation and solar radiation), physical factors such as elevation, hillshade, slope, soil depth, accessibility to the fields and land use cover were used to produce wheat suitability map. All inputs were weighted with reference to existing wheat areas. MCA and ANN approaches were applied using same dataset to compare the performance of the two techniques. In total, 228 wheat parcels were used as training (171 parcels) and testing (57 parcels) data. Relative Operational Characteristic (ROC) was applied for accuracy assessment. ROC values of the MCA technique which was depended on existing wheat lands, and ANN techniques were derived to be 0.875 and 0.71 respectively. Results showed that $15 \%$ of the research area was very suitable for wheat farm, and today, only $67 \%$ of very suitable areas were used to be agriculture. Other areas were currently used as grassland (28\%), bare ground $(4 \%)$, and other $(1 \%)$.
\end{abstract}

\section{Veri Bağımlı Yaklaşımlarla Coğrafi Çevresel Faktörler Dikkate Alınarak Buğday Tarımı için Alan Kullanım Uygunluğunun Değerlendirmesi}

\section{Makale Bilgileri}

Geliş: 18.03 .2021

Kabul: 02.06.2021

Online Yayınlanma: 15.09.2021

DOI: 10.29133 /yyutbd. 898307

\section{Anahtar Kelimeler}

Tarımsal alan kullanım uygunluğu,

Buğday,

Çok ölçütlü değerlendirme, Yapay sinir ağları, CBS.
Öz: Temel çevresel faktörler dikkate alınarak, standart sapma tabanlı çok ölçütlü değerlendirme (ÇÖD) ve yapay sinir ağları (YSA) olarak iki teknik, Van Bölgesi'ndeki buğday tarımına uygun alanların belirlenmesi için araştırılmıştır. İklim verileri (uzun dönemli en yüksek, en düşük, ortalama sıcaklıklar, toplam yağış ve güneş radyasyonu), yükseklik, tepe gölgelikleri (güneşlenme), eğim, toprak derinliği, alansal erişilebilirlik ve arazi örtüsü ve kullanımı verileri buğday tarımı için uygun alanların belirlenmesinde kullanılmıştır. Bütün kullanılan girdi verileri, sezonluk buğday tarımı yapılan alanlar temel alınarak ağırlıklandırılmıştır. ÇÖD ve YSA aynı girdi verileri kullanılarak performans değerledirmesi için karşılaştırılmıştır. Toplamda 228 buğday parselinin 171'i eğitim verisi ve 57 parseli ise test verisi olarak kullanılmıştır. Göreceli çalışma karakteristiği (GÇK), doğruluk analizi için uygulanmıştır. ÇÖD ve YSA tekniklerinin GÇK doğruluk katsayıları sırasıyla; 0.875 ve 0.71 olarak elde edilmiştir. Çalışma sonuçlarına göre; Van İli arazilerinin \% 15'inin buğday tarımına çok uygun olduğu ancak bu alanların \% 67'sinin tarım için kullanıldığı, geri kalan alanların \% 28'inin çayır-mera, \% 4'ünün açık alan ve \% 1'inin ise diğer alanlardan oluştuğu belirlenmiştir. 


\section{Introduction}

Studies on climate change showed that global warming, soil erosion, land degradation and hydrological changes may cause a global famine in the near future (Arnell 1999; Parry et al. 1999). Therefore, it is necessary to determine sustainable land use strategies for optimal use of our land and water resources.

Agricultural lands were decreased around $0.1-0.2 \%$ between 2009 and 2013 all over the world (WB, 2013). However, world's population was increased $6.2 \%$ in the same period (UN, 2013). This situation is even severe in fast developing countries like Turkey where the population raised $5.4 \%$, agricultural lands were decreased around 3.2\% between 2009 and 2013 in Turkey (TSI, 2013). As a result of agricultural area loss, agricultural land use planning has been more important than before. Today, land use plans are required spatial information technologies including, Geographical Information System (GIS) and Remote Sensing (RS). Malczewski (2007) indicated that 8.5\% of the scientific papers in between 1990 and 2004 were on MCA and GIS usage in agricultural decision making process.

Decision support systems utilised widely combined with GIS in land use planning, and this process is called spatial decision support system (SDSS). This system has a wide range of usage purpose such as urban land use planning (Mosadeghi et al. 2015), tourism and recreational area planning (Bunruamkaew and Murayama, 2011), agricultural land use planning (Kalogirou, 2002). A SDSS is included weighting factors (criteria) as a most critical stage that is directly affected the accuracy of study. There are several approaches for weighting the factors and three of them are very common in the literature to be; i) expert based weighting, ii) literature based weighting, and iii) Existed or ideal data based weighting approaches. Additionally, there are non-parametric techniques like artificial neural network (ANN) and support vector machine (SVM), and they have an internal weighting ability based on training data (ideal point or grid data) (Satir et al. 2016).

Expert-based methods are generally preferred in cases where the training data are scarce. Because, priority of the factors is evaluated by the experts through a survey. Following to this expert evaluation, the weighted factors can be integrated to analytical hierarchical process (AHP) due to pairwise comparison ability. Pairwise comparison matrix is defined weights using binary priority definition (Saaty, 1980; 2008). Although this method is easily applicable, there is still a subjective side because of expert differences and experience. Literature based technique is another approach to define the factor priorities. It is applied based on previous studies that are similar with main study. This method is easy for weighting definition, however; regional environmental and social differences are ignored, so solidity of the technique is questionable (Şatir, 2016). MCA approach based on ideal data is more objective than other techniques. In this approach, some of the indicators can be used to define ideal areas such as crop productivity or existed cropping areas to map crop suitability (Şatır, 2013; Satir and Berberoglu, 2016).

Wheat is one of the oldest cultivated crops in Anatolian region. According to the studies in Anatolian region, the history of wheat farming goes back to 8000 - $10.000 \mathrm{BC}$ (Kan et al. 2015; Bilgic et al. 2016). Anatolia is still contained more than 100 wild wheat populations (Karagöz et al. 2006). In this study, wheat farming suitability was evaluated in Van city that is located in sub-alpine Eastern Turkey. According to the FAO projections on wheat crop, potential production of Turkey two times more than current version (FAO, 2002). Therefore, wheat is a good indicator for agricultural suitability detection in dry and cold regions because of wide range of the cultivated areas and species diversity in Eastern Anatolian Region (EAR). Additionally, wheat farming has been developed day by day in Eastern Anatolia because of climate change and immigrations from village to the towns (Şatır et al. 2017). Wheat cultivated areas were increased almost 3\% in last 5 years (2015-2020). Additionally, crop productivity has been improved during the same period in Van region of Turkey (TSI, 2020).

Main purpose of this research was to estimate the potential wheat growth suitability in a subalpine region of Turkey comparing two commonly used objective data dependant approaches. In this paper, potential wheat growth suitability was evaluated by aid of existing wheat lands in Van Province, Turkey. Physical (elevation, slope, hill shade, soil depth), long term climate (annual maximum, minimum and mean temperature, total annual mean precipitation, total annual solar radiation) and social datasets (distance from roads, LUC) were used to be predictors. So that suitability maps for wheat farming were derived using these inputs and results enable for stakeholders to build more sustainable agricultural land management strategies in the physically hard conditions such as studied region. 


\section{Material and Methods}

\subsection{Study Area}

Van province is located in the Eastern Turkey on the Van Lake coast (the largest lake in Turkey) and it covers $21.334 \mathrm{~km}^{2}$ area (Figure 1). Population is 1.123 .784 , and it is 19 th most populated city of Turkey (TSI, 2018). The main incomes are animal husbandry and processing industry, agriculture and tourism. Region has continental and sub-alpine climate characteristics dominated by cold and dry climate. Mean annual temperature is between 5 and $10{ }^{\circ} \mathrm{C}$, and total annual precipitation is between 400 $-850 \mathrm{~mm}$ in the region. Wheat, barley, clover, sainfoin and vetch farms are the common field crops. Elevation range in the region is between $1000 \mathrm{~m}$ and $3700 \mathrm{~m}$.

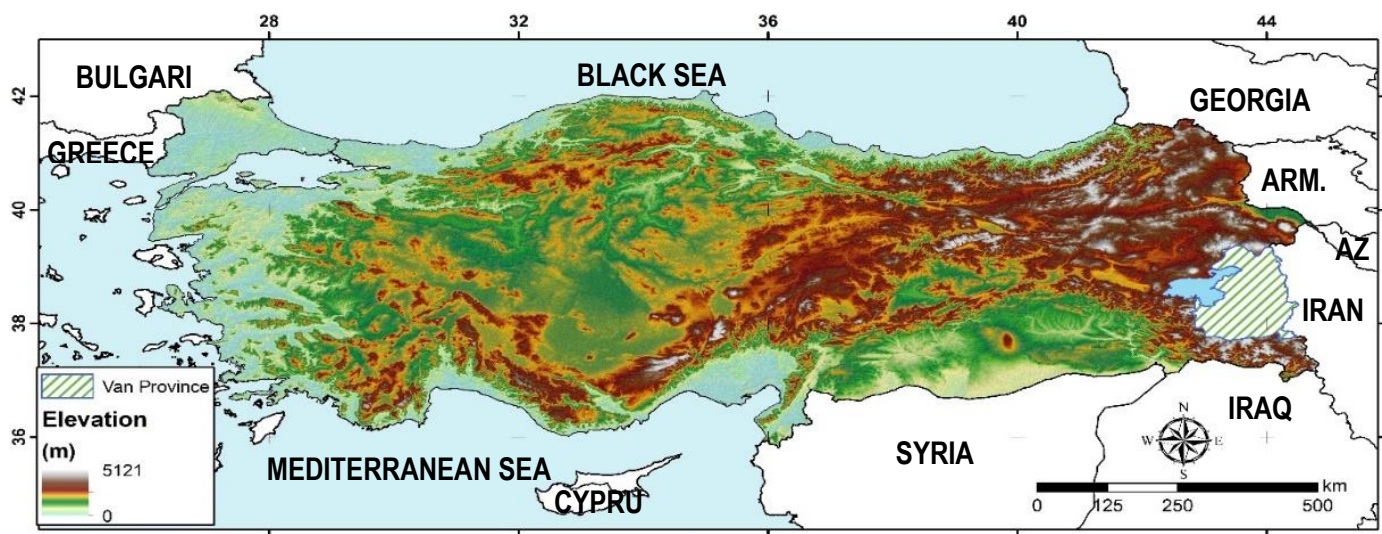

Figure 1. Location of the study area (Van Province).

\subsection{Main Dataset}

Five main datasets were used in the study; existed wheat fields, DEM data derived from ASTER stereo images, main road networks, long term climate dataset (2006 - 2015) and soil data (Table 1).

Table 1. Specifications of main dataset used in the study

\begin{tabular}{|c|c|c|}
\hline Dataset & Usage purpose & Source \\
\hline Existing wheat fields & Training and testing the results & $\begin{array}{l}\text { Van provincial directorate of } \\
\text { Agriculture }(2014-2015)\end{array}$ \\
\hline $\begin{array}{l}\text { Long term climate } \\
\text { dataset }\end{array}$ & $\begin{array}{l}\text { Mean, max. and min. temperature, } \\
\text { precipitation and solar radiation } \\
\text { mapping by interpolation techniques }\end{array}$ & TSMS $(1975-2015)$ \\
\hline Main road network & Defining the accessibility of the fields & $\begin{array}{l}\text { General directorate of } \\
\text { highways (2015) }\end{array}$ \\
\hline Digital elevation model & $\begin{array}{l}\text { Obtaining the physical variables such } \\
\text { as elevation, slope, sun availability. }\end{array}$ & $\begin{array}{l}\text { ASTER stereo images GDEM } \\
\text { data }\end{array}$ \\
\hline Soil dataset & Defining the Soil depth & $\begin{array}{l}\text { General directorate of Village } \\
\text { service (1996) }\end{array}$ \\
\hline
\end{tabular}

\subsubsection{Wheat Fields Data}

This data set was provided by Van provincial directorate of agriculture (VPDA) for 2014 and 2015. In total 238 winter wheat field data were collected considering elevation, slope and climatic variables. Wheat parcels were separated two parts for training (171 parcels) and testing (57 parcels) respect to the variability of inputs (Figure 2). 


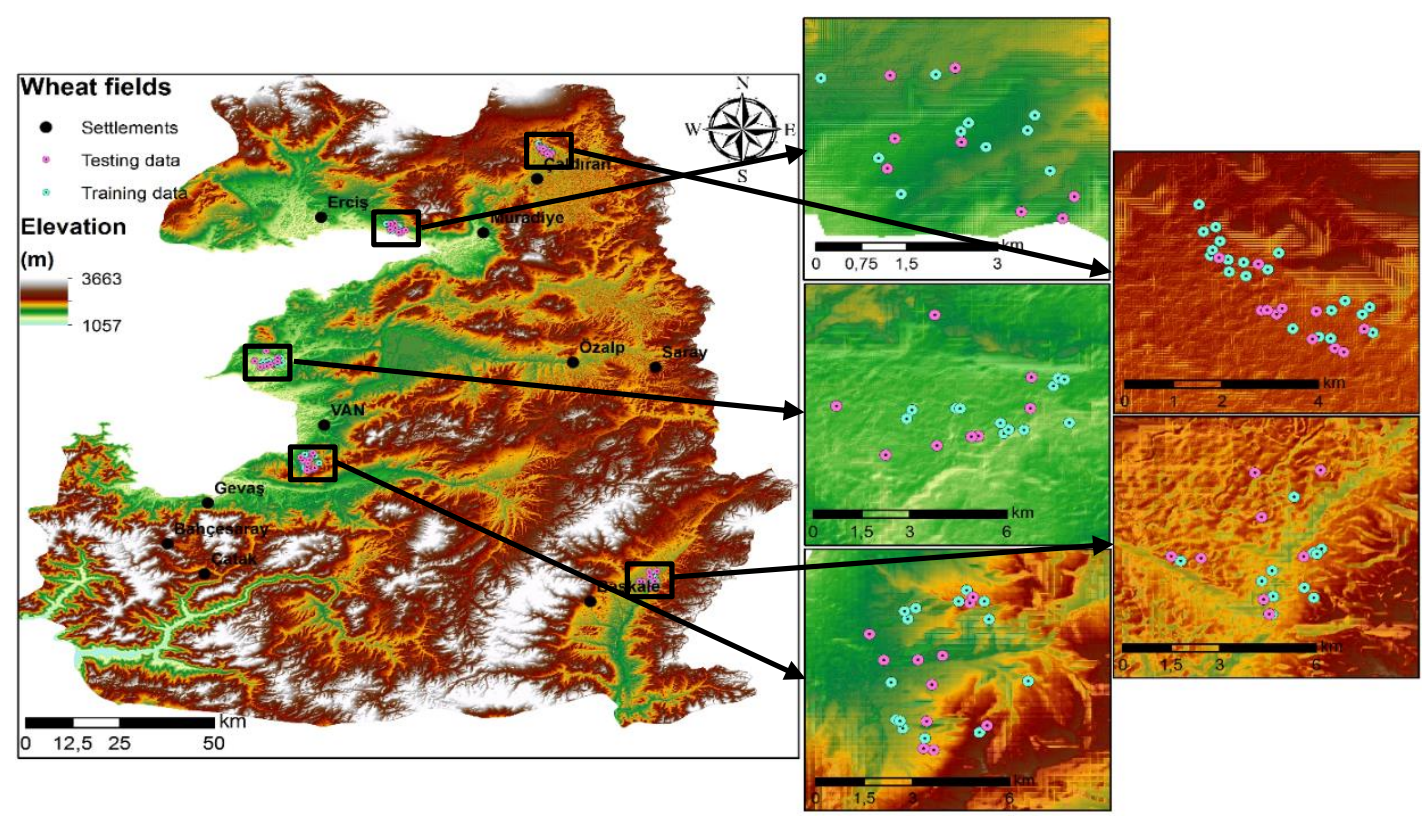

Figure 2. Distribution of existed wheat fields (location of the parcel centers).

\subsubsection{DEM and Main Road Networks}

DEM data was derived from ASTER stereo images in 30m spatial resolution. Slope and hillshade were produced using DEM. Main road network includes only asphalt roads and this data derived using main road network map of Turkey from General Directorate of Highways.

\subsubsection{Climate Dataset}

Long term (2006 - 2015) maximum, minimum and mean temperature, total annual precipitation and solar radiation dataset were obtained from 12 climate stations. These climate data were mapped using appropriate radial based function. Climate stations have been calibrated regularly by the Turkish State Meteorological Services (TSMS, 2015). Long term climate dataset was used because of avoiding the seasonal climatic variability in the region.

\subsubsection{Soil Data}

Soil data has course spatial resolution in raster format, only soil depth was used because of its importance in wheat cultivation. Soil dataset are also showed land use ability based on slope and erosion and main soil groups. However, slope data has already been used as a factor. Soil depth data showed five categories from 0 to $120+\mathrm{cm}$ in the map.

\subsection{Method}

Method of the study contains four main stages; i) criteria selection and preparation, ii) standardization and weighting of the factors, iii) ANN application and, iv) accuracy assessment. All factors were defined according to the effects on wheat growth and dataset accessibility. Climate, physical, social, soil and field datasets were pre-processed before the multi-criteria analyse (MCA) (Figure 3). 


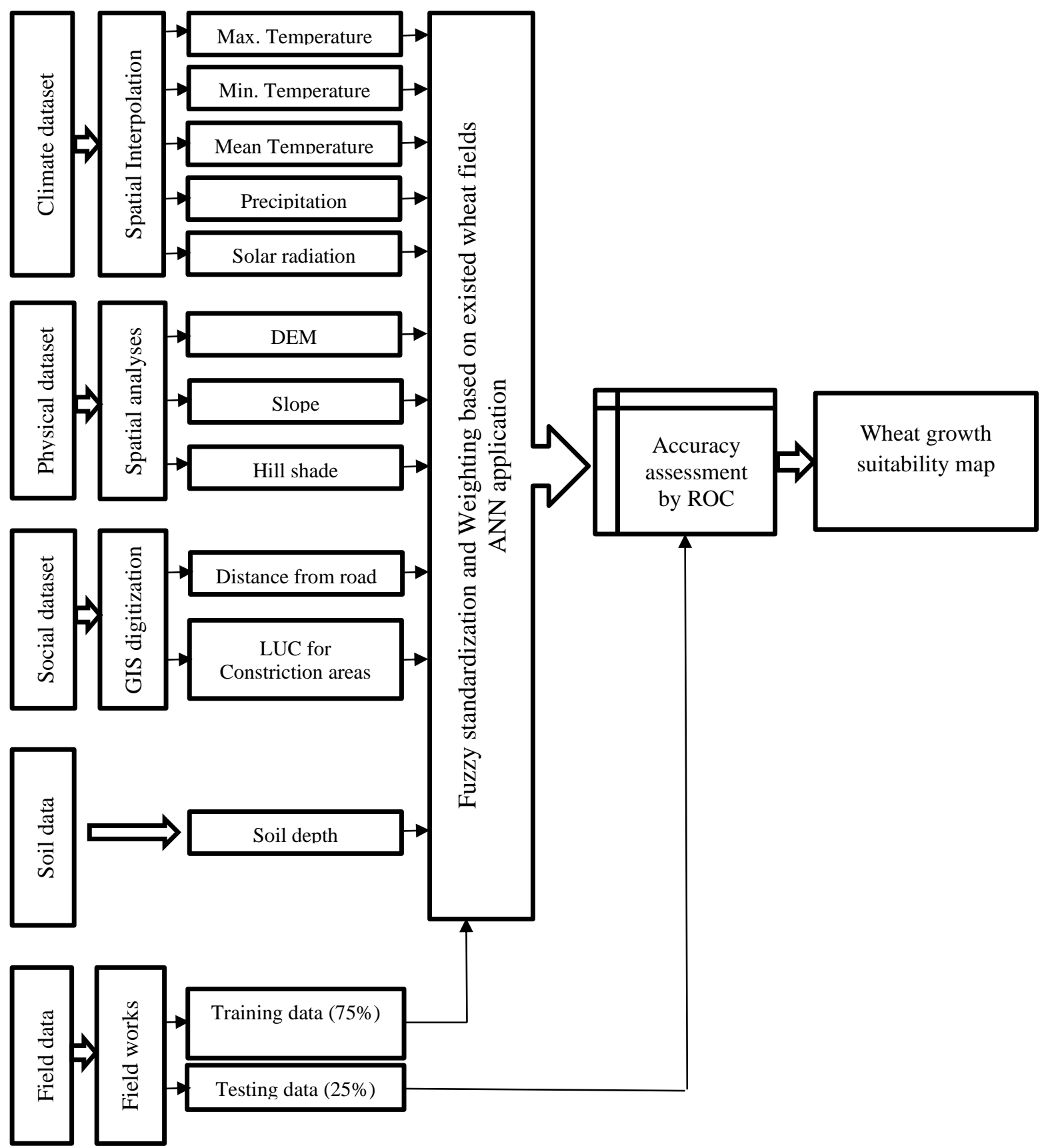

Figure 3. Research flow for mapping the wheat growth suitability.

\subsubsection{Factor Selection and Preparation}

Slope and hillshade were produced using standard spatial analyses tools within a GIS environment from DEM data. Elevation is very important factor for the crop productivity. It is directly related with atmospheric variables such as temperature. Additionally, slope is another factor for economic farming. Sun illumination effect was evaluated using hill shade, as a vital factor for crop growth.

Climate variables were mapped using radial basis function (RBF) interpolation technique that has been used widely in regional studies (Satir and Berberoglu, 2016). RBF is a one of the most used geo-statistical model which contains an algorithm to predict unknown spatial point values from known values (Barton et al., 1999). Simply, RBF run by Euclidian distance in a linear system. However, prediction line can be defined according to the prediction function type such as gaussian, quadratic or cubic. 
Euclidian distance of the main roads were mapped using distance tools in GIS. So, accessibility of the fields was evaluated. Additionally, LUC map was used to mask restricted areas from final results such as, water bodies, existed built up areas, restricted zones and nature protection areas.

\subsubsection{Standardization and Weighting}

In a multiple data assessment technique, value range of input data layers can be variable such as, slope factor ranges between 0 and 90 degree, whereas elevation can be in between $1000 \mathrm{~m}$ and $2000 \mathrm{~m}$. Therefore, each factor must be standardized in a pre-defined range according to the research goals, and it has been usually between 0 and 1 . Thus the priority of each factor can be comparable with each other.

Fuzzy standardization technique was applied to the all inputs to obtain more accurate results (Mosadeghi et al. 2015). Fuzzy standardization idea is based on soft limits (boundaries) as hard boundaries are inapplicable between two different landscapes in the nature. So, fuzzy technique considers a transition zone between suitable and not suitable regions. Fuzzy set functions can be sigmoidal, gaussian, linear or user defined. Function form is very flexible according to the factor type and study goal like gaussian, monotonically increased or decreased forms (Kavzoglu et al. 2014).

Weighting process is one of the critical issues in a multiple data assessment technique for land use suitability or geographical risk analysis (Şatir, 2016). Ideal point based weighting was used in this study. Existing wheat fields were divided two parts as, training (75\%) and testing (25\%). Training dataset was used to derive weights of each factor. In this stage, factors were categorized individually with respect to impacts on wheat cultivation, and distribution of the training data in each category was detected. In the second part, standard deviation (SD) of each factor was calculated based on training data distribution. Small SD value of a factor indicates homogenous distribution of training data, which means this factor has low impact on wheat growth. Oppositely, if the training data distribution is heterogeneous in each category, it is referred that factor priority on wheat growth is high.

\subsubsection{ANN Approach}

The multilayer perceptron (MLP) approach that has been the most commonly encountered ANN model in data analysis and remote sensing (because of its generalization capability) was used in this study (Rumelhart et al. 1986). Crop suitability mapping by ANN was applied in three stages to be; training, allocation and testing. In training stage, ideal and non-ideal data values are matched with input variables, and neural system is trained. Backpropagation algorithm that is most commonly used algorithm were used with generalized delta rule (Rumelhart et al. 1986). In this algorithm, network is trained iteratively until: (1) the maximum number of pre-specified iteration was reached, (2) performance had met a suitable level, and (3) the gradient was below a suitable target. Optimal model can be determined experimentally. In this paper, the basic feed forward, back-propagation ANN described above is used as a regression model to estimate the wheat farm suitability based on geoenvironmental inputs.

\subsubsection{Relative Operating Characteristic}

The Relative Operating Characteristic (ROC) is a reliable technique to test a Boolean and continuous dataset. For example, the ROC could be used to compare an estimated probability for fire risk against a fire occurrence dataset (Satir et al. 2016). The ROC is showed "how match the Boolean and continuous dataset in each category". It is mean that how successful dataset " $A$ " to identify dataset "B. Thus, the ROC analysis is useful for cases in which the scientist wants to see how well the probability map portrays the location of a particular category but does not have an estimate of the quantity of the category.

\section{Results}

The results were presented in three sub-sections (Input data preparation, wheat suitability analyses and accuracy assessments). 


\subsection{Input Data Preparation}

Climate, physical and social datasets were mapped before the MCE process. Climate dataset was interpolated using RBF. Long term (2006 - 2015) minimum, maximum, mean temperatures, annual precipitation and solar radiation maps were produced. Annual maximum and minimum temperature were around $22^{\circ} \mathrm{C}$ and $-8.5^{\circ} \mathrm{C}$ respectively. Van Lake has warming effect in the region on temperature. Long term annual total precipitation was mapped within the range of $391 \mathrm{~mm}$ and $828 \mathrm{~mm}$ for the study area, and particularly, south-western side receive more precipitation than other parts (Figure 4). Precipitation and solar radiation of the study area are more heterogeneous than temperatures, according to standard deviation of the climate dataset (Table 2).

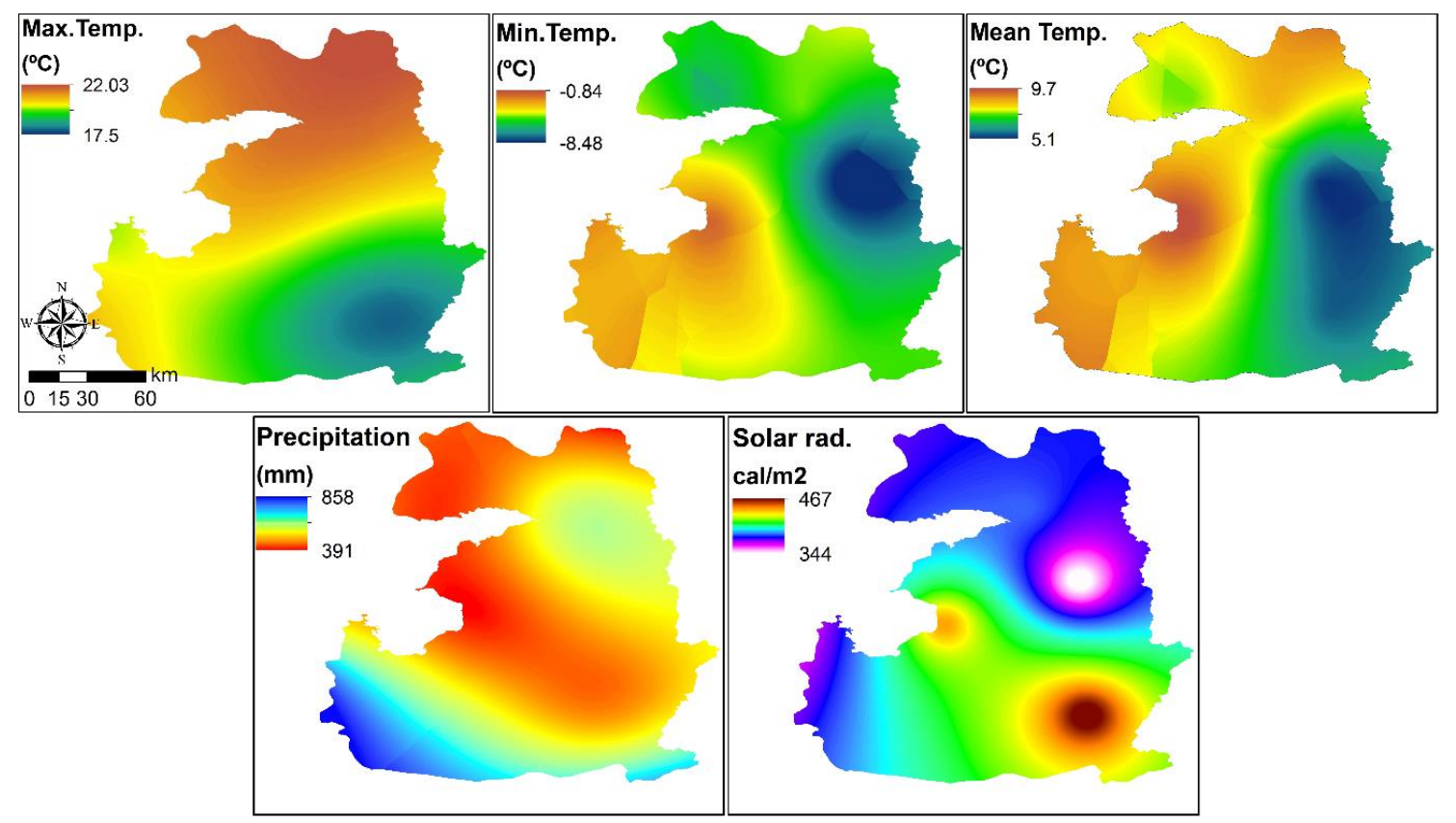

Figure 4. Interpolated long term annual climate dataset.

Table 2. Spatially distributed climate dataset characteristics of the study area

\begin{tabular}{lrrrr}
\hline Climate data & $\begin{array}{c}\text { Max. } \\
\text { value }\end{array}$ & Min. value & $\begin{array}{r}\text { Mean } \\
\text { value }\end{array}$ & $\begin{array}{r}\text { Standard } \\
\text { deviation }\end{array}$ \\
\hline Annual Maximum Temperature $\left({ }^{\circ} \mathrm{C}\right)$ & 22 & 17.4 & 20 & 1.3 \\
Annual Minimum Temperature $\left({ }^{\circ} \mathrm{C}\right)$ & -0.8 & -8.5 & -4.3 & 1.6 \\
Annual Mean Temperature $\left({ }^{\circ} \mathrm{C}\right)$ & 9.6 & 6.1 & 7.8 & 0.9 \\
Annual Total Precipitation $(\mathrm{mm})$ & 858 & 391 & 524 & 95.1 \\
Annual Total Solar Radiation $\left(\mathrm{cal} / \mathrm{m}^{2}\right)$ & 467 & 343.8 & 400 & 22.9 \\
\hline
\end{tabular}

Physical and social dataset: Hillshade and slope data were produced from DEM, and altitude, hillshade and slope were used within the analysis. Additionally, soil depth data was provided by VPDA in grid format with scale of $1 / 100000$. Only road network data was used to consider the accessibility of the croplands as a social factor. Additionally, distance from main road networks map was derived for these analyses in a GIS environment (Figure 5). 


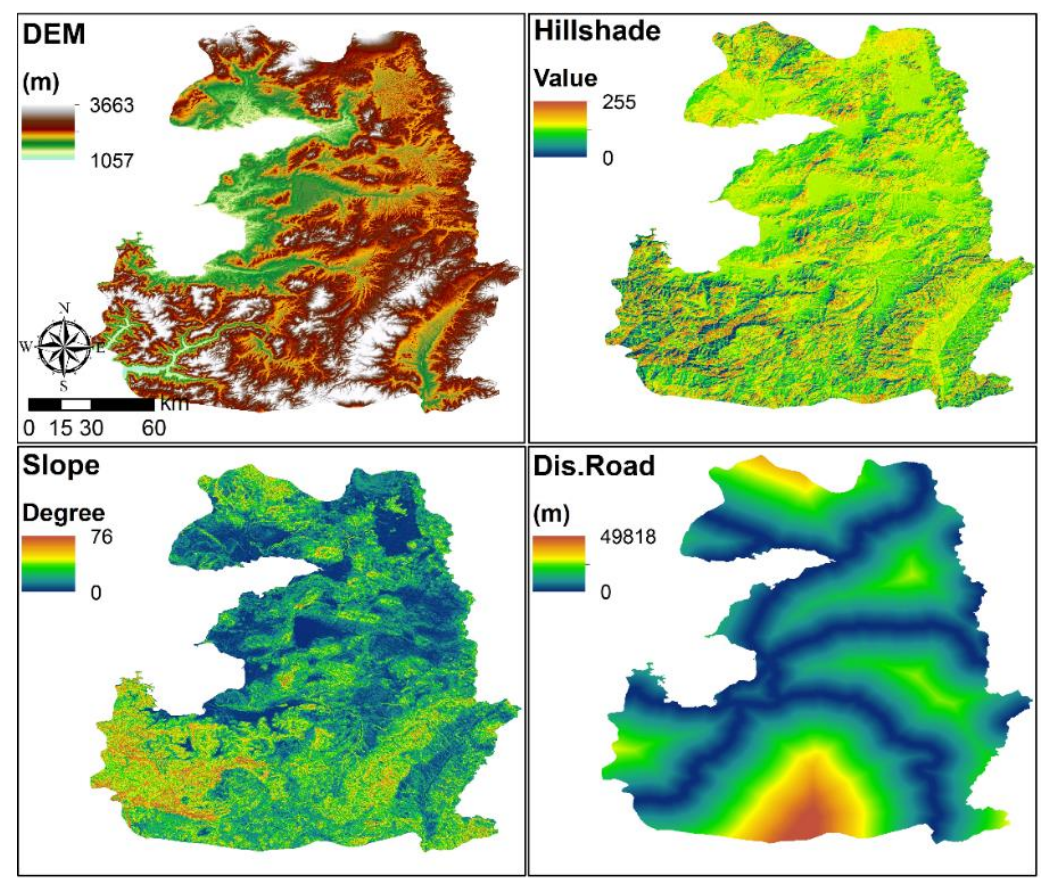

Figure 5. Produced physical and social dataset.

\subsection{Wheat Suitability Analyses}

Two approaches were applied to obtain wheat suitability map to be standard deviation based linear MCA and non-linear ANN based multi data assessment approaches.

In the first technique, suitability analysis was applied in three steps; i) Fuzzy based standardization of factors derived from existing wheat fields, ii) Weighting of inputs from first step utilising existing wheat field heterogeneity (Standard deviation) and iii) mapping the results in continuous and categorical form.

\section{i) Standardization}

Each input data has its own data range and unit, so all input variables were standardized using fuzzy approach, and range of the input dataset was set between 0 and 1 according to the wheat growth suitability. In this extent, input dataset was categorized based on distribution of the existing wheat fields to define appropriate fuzzy membership function type such as linear, sigmoidal or user defined. For example, long term total annual precipitation and distribution of wheat parcels in each precipitation categories were analysed, and a linear decreasing relationship was detected (Figure 6).
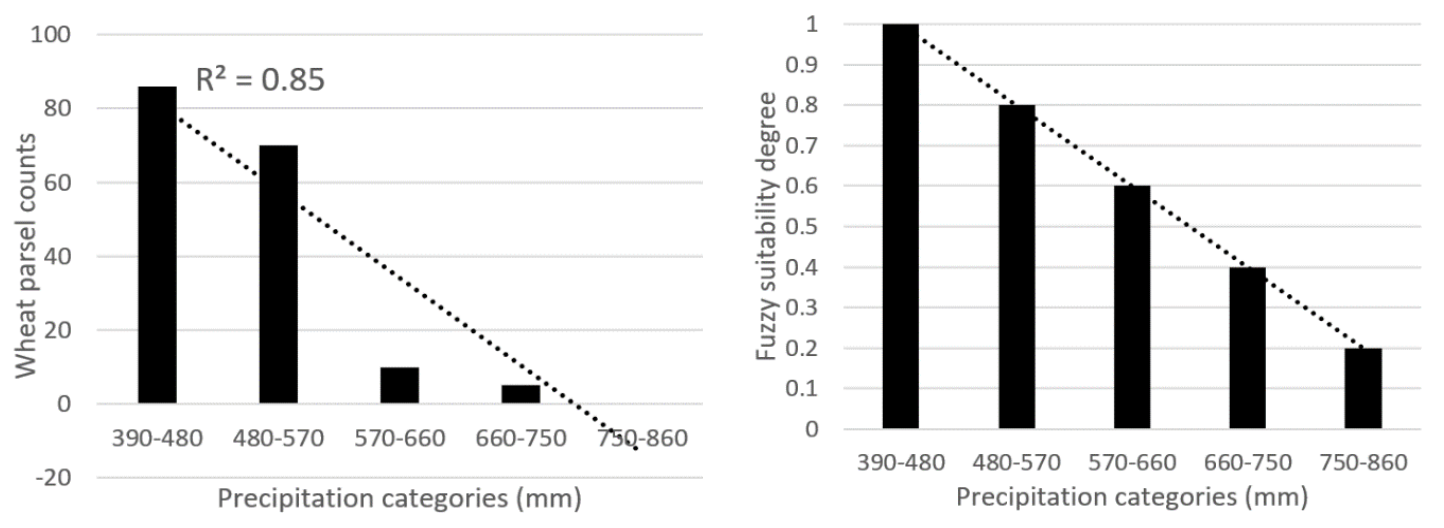

3.

Figure 6. Sample precipitation fuzzy standardization for wheat suitability. 
Input variables and fuzzy membership function types for standardizations were shown in table 3. Standardized inputs variables were derived based on existing wheat field distribution (Figure 7).

Table 3. Fuzzy membership function types for standardization

\begin{tabular}{lrccc}
\hline Input variables & $\begin{array}{c}\text { Original data } \\
\text { range }\end{array}$ & Unit & $\begin{array}{c}\text { Fuzzy membership } \\
\text { function type }\end{array}$ & $\begin{array}{c}\text { Standardized } \\
\text { data range }\end{array}$ \\
\hline Min. Temperature & $-0.8--8.5$ & ${ }^{\circ} \mathrm{C}$ & Gaussian & \\
Max. Temperature & $17.5-22$ & ${ }^{\circ} \mathrm{C}$ & Linear Decreasing & \\
Mean Temperature & $5.1-9.7$ & ${ }^{\circ} \mathrm{C}$ & Linear Increasing & \\
Precipitation & $391-858$ & $\mathrm{~mm}$ & Linear Decreasing & \\
Solar Radiation & $344-467$ & $\mathrm{cal} / \mathrm{m}^{2}$ & Gaussian & $0-1$ \\
Elevation & $1057-3663$ & $\mathrm{~m}$ & User defined & \\
Slope & $0-76$ & $\mathrm{o}$ & Sigmoidal Decreasing & \\
Hillshade & $0-255$ & value & User defined & \\
Soil Depth & $0-120$ & $\mathrm{~cm}$ & User defined & \\
$\begin{array}{l}\text { Distance from } \\
\text { roads }\end{array}$ & $0-50000$ & $\mathrm{~m}$ & Sigmoidal Decreasing & \\
\hline
\end{tabular}

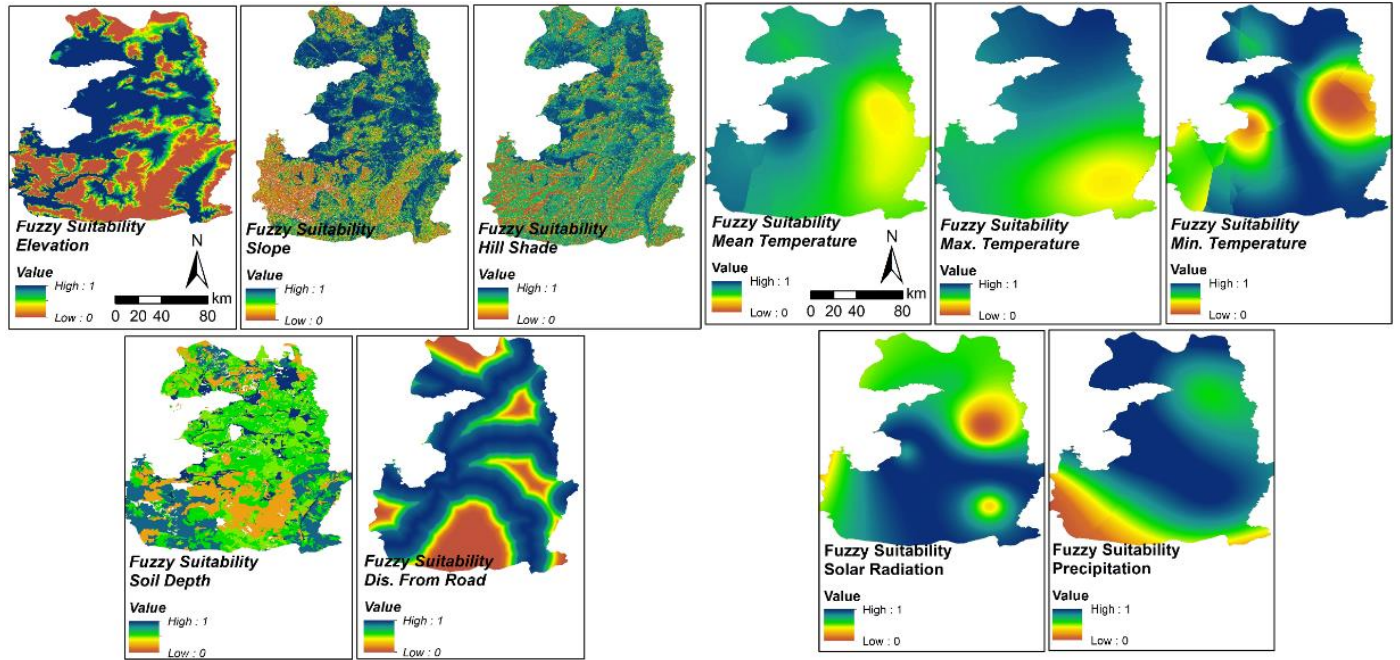

Figure 7. Fuzzy standardization results

\section{ii) Weighting}

In this study, 10 geo-environmental factors were considered to map the suitable lands for wheat growth. All factors are of different effects on wheat growth, and some of them more important than others. There are many approaches to define the priority of the factors, and some of the common techniques were described in introduction section.

Ideal point based weighting approach was used because this technique is more objective than others. In this context, 171 wheat parcels were assessed according to the parcel distribution and frequencies in each category. First of all, factors were categorized based on effects on the wheat growth. For instance, all temperature dataset was reclassified by considering $1^{\circ} \mathrm{C}$ difference. In precipitation, 90 $\mathrm{mm}$ interval was applied for categorization. In second stage, distribution of the 171wheat parcels in each category have been detected, and in the last stage, heterogeneity of the wheat parcels in each category was evaluated through standard deviation analysis. The hypotheses of this stage are;

a) If the distribution of the wheat parcels is homogeneous, this factor has weak impact on wheat growth, because variability of the factor is ineffective.

b) If the distribution of the wheat parcels is heterogeneous, this factor has a significant effect on wheat growth. Because variability of the factors is effective on wheat growth suitability. 
Priorities (weights) of the factors (inputs) were detected according to the standard deviation (SD) values of the wheat area distribution of each category. Large SD value means that heterogeneity of the factor is high, and it has a significant effect on wheat growth (Table 4).

In the second approach, ANN based wheat suitability degrees were detected. MLP based ANN consist of 5 main variables to be (1) size of the training data, (2) the network architecture, (3) the learning rate, (4) the learning momentum and (5) the number of training cycles that have direct effects on accuracy.

Size of training data must be characterized to the studied field on wheat farm suitability. In total, 238 field data were used to get the wheat suitability and distribution of the fields were selected considering physical and climatic variability.

Network architecture of the study consist of 8 input neurons (Elevation, slope, hill shade, soil depth, annual maximum, minimum and mean temperature, total precipitation and distance from road), 17 hidden neurons and 2 output neurons (suitable and non-suitable). Single hidden layer was used in the study and hidden neuron count was defined experimentally.

The learning rate determines the portion of the calculated weight change that will be used for weight adjustment. This value range is between 0 and 0.99 . In this study small learning rate was used to be 0.01 . However, small learning rate needs more training cycles than big one.

Learning momentum is used to allocate learning rate. It takes values between 0.1 and 0.9 . Also, this value can be defined experimentally, in our study it was defined as 0.5 .

The number of training cycles was defined according to the testing and training accuracy. In MLP technique, training and testing accuracy of the network has been increased in each iteration until the ketch stable line. In our study, stable line was obtained around 18000 iterations, but system has been worked until the 50000 iterations to see the late break points (Figure 8).

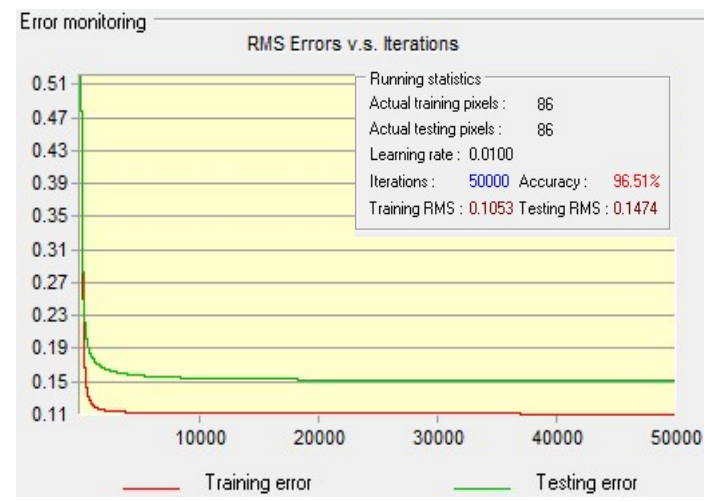

Figure 8. Testing and training error monitor of the ANN. 
Table 4. Weights and priority ranks of geo-ecological factors

\begin{tabular}{|c|c|c|c|c|}
\hline Factors & $\begin{array}{l}\text { Categories: Data range: } \\
\text { wheat parcel counts }\end{array}$ & SD values & Weights & $\begin{array}{r}\text { Priority } \\
\text { Rank } \\
\end{array}$ \\
\hline $\begin{array}{l}\text { Max. Annual Temp. } \\
\left({ }^{\circ} \mathrm{C}\right)\end{array}$ & $\begin{array}{l}1: 17-18: 28 \\
2: 18-19: 0 \\
3: 19-20: 0 \\
4: 20-21: 66 \\
5: 21-22: 77\end{array}$ & 36.12 & 0.082 & 5 \\
\hline $\begin{array}{l}\text { Min. Annual Temp. } \\
\left({ }^{\circ} \mathrm{C}\right)\end{array}$ & $\begin{array}{l}1:-0.9-0.3: 0 \\
2: 0.3-1.5: 0 \\
3: 1.5-2.7: 0 \\
4: 2.7-3.9: 54 \\
5: 3.9-5.1: 51 \\
6: 5.1-6.3: 1 \\
7: 6.3-7.5: 28 \\
8: 7.5-8.7: 37\end{array}$ & 23.95 & 0.054 & 10 \\
\hline $\begin{array}{l}\text { Mean annual Temp. } \\
\left({ }^{\circ} \mathrm{C}\right)\end{array}$ & $\begin{array}{l}1: 5-6: 28 \\
2: 6-7: 0 \\
3: 7-8: 10 \\
4: 8-9: 68 \\
5: 9-10: 65\end{array}$ & 31.16 & 0.071 & 8 \\
\hline $\begin{array}{l}\text { Annual Total } \\
\text { Precipitation (mm) }\end{array}$ & $\begin{array}{l}1: 390-480: 96 \\
2: 480-570: 75 \\
3: 570-660: 0 \\
\text { 4: } 660-750: 0 \\
5: 750-860: 0\end{array}$ & 47.41 & 0.108 & 4 \\
\hline $\begin{array}{l}\text { Annual total solar } \\
\text { radiation }\left(\mathrm{cal} / \mathrm{m}^{2}\right)\end{array}$ & $\begin{array}{l}\text { 1: Very low: } 0 \\
\text { 2: Low : } 77 \\
\text { 3: Medium : } 29 \\
\text { 4: High : } 54 \\
\text { 5: Very high: } 11\end{array}$ & 31.45 & 0.072 & 7 \\
\hline Slope (degree) & $\begin{array}{l}1: 0-5: 165 \\
2: 5-10: 4 \\
3: 10-15: 2 \\
4: 15-20: 0 \\
5: 20-25: 0 \\
6: 25-30: 0 \\
7: 30-35: 0 \\
8: 35<\ldots: 0\end{array}$ & 58.05 & 0.133 & 3 \\
\hline $\begin{array}{l}\text { Hillshade (sun } \\
\text { effect) }\end{array}$ & $\begin{array}{ll}\text { 1: Very low } & : 0 \\
\text { 2: Low } & : 0 \\
\text { 3: Medium } & : 7 \\
\text { 4: High } & : 163 \\
\text { 5: Very high } & : 1\end{array}$ & 72.06 & 0.164 & 2 \\
\hline Elevation (m) & $\begin{array}{l}1: 1050-1350: 0 \\
2: 1350-1750: 23 \\
3: 1750-2150: 87 \\
4: 2150-2450: 61 \\
5: 2450-2750: 0 \\
6: 2750-3050: 0 \\
7: 3050-3350: 0 \\
8: 3350-3650: 0\end{array}$ & 34.15 & 0.078 & 6 \\
\hline $\begin{array}{l}\text { Distance from main } \\
\text { roads }(m)\end{array}$ & $\begin{array}{ll}1: 0-5000 & : 171 \\
2: 5000-10000 & : 0 \\
3: 10000-15000: 0 \\
4: 15000-20000: 0 \\
5: 20000<\ldots \quad: 0\end{array}$ & 76.47 & 0.174 & 1 \\
\hline Soil depth $(\mathrm{cm})$ & $\begin{array}{l}1: 0-20: 37 \\
2: 20-50: 57 \\
3: 50-90: 6 \\
4: 90-120: 5 \\
5: 120<\ldots: 66\end{array}$ & 28.22 & 0.064 & 9 \\
\hline
\end{tabular}


iii) Wheat suitability maps and accuracy assessment

In linear technique, standardized factors were multiplied by the weights and suitability degree of the wheat areas were produced. Constrains such as water bodies, existing settlement areas and roads, airport area and bulrush areas were masked out from the final maps. Predicted wheat suitability map was tested using 57 existing wheat parcels using ROC analyse. ROC co-efficiency was 0.875 . This result indicated that this method was capable to map wheat suitability accurately in the region. Suitability degree map was divided into five categories including very high, high, medium, low, very low to demonstrate the spatial diversity of wheat growth suitability clearly. In total, $19.104 \mathrm{~km}^{2}$ area was classified to be $14 \%$ very high, $30 \%$ high, $31 \%$ medium, $17 \%$ low and $3 \%$ very low wheat growth suitability. Additionally, almost $3 \%$ of the area was ignored because of restrictive characteristics (Figure 9).
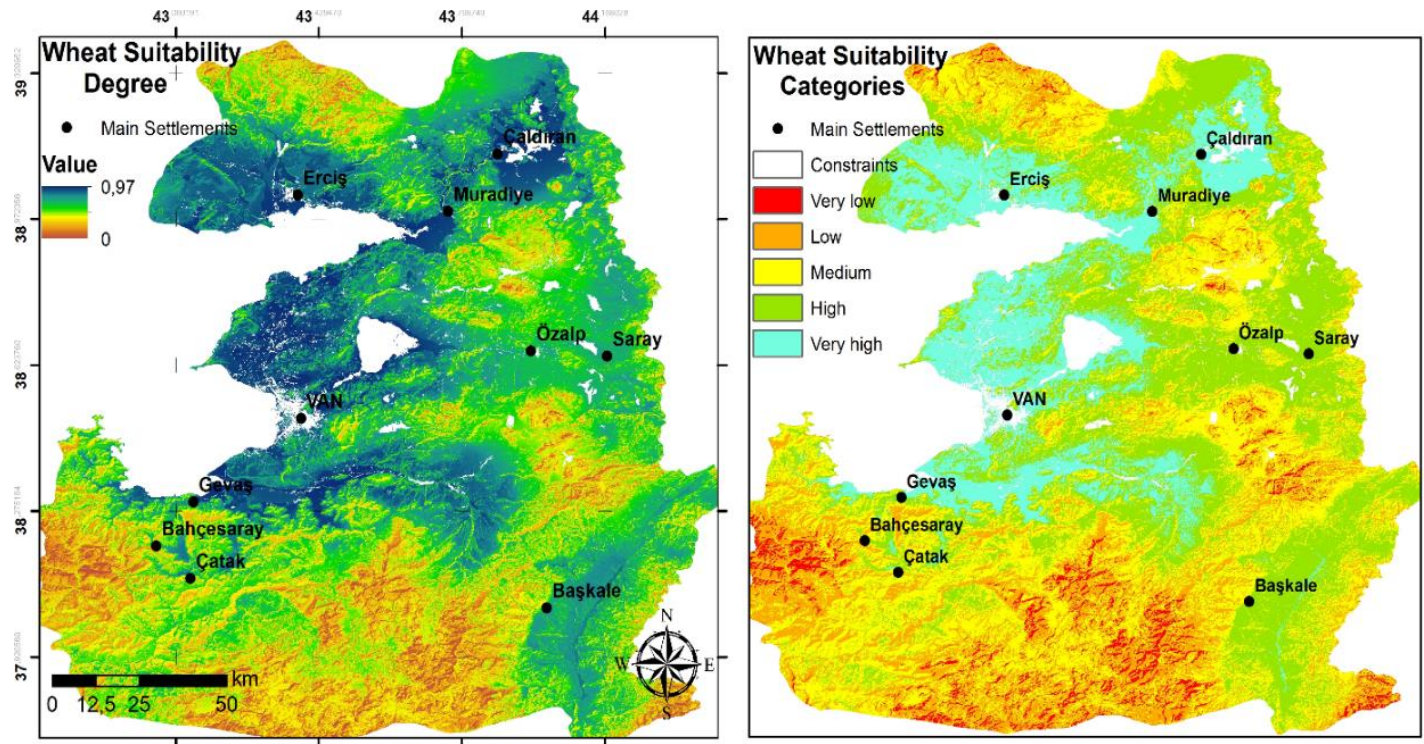

Figure 9 . Wheat suitability maps by linear approach (MCA).

In ANN technique, weighting was performed automatically based on existed wheat areas. ROC statistic was applied using same testing dataset with linear method. ROC co-efficiency was obtained to be 0.71 for ANN analyses. Wheat suitability categories were classified as $32 \%$ very high, $9.4 \%$ high, 9.6\% medium, $11.7 \%$ low and $34.3 \%$ very low respectively. ANN result was not match very well with testing data according to the ROC value. Because, 0.71 was lower than 0.75 threshold and it is mean that the ANN result was matched with testing data slightly (Figure 10).

The highest suitable regions (very high suitability) were compared by current Land Use Cover (LUC) maps of the region that was produced by Satir et al. (2016) according to the CORINE Level 1 classification scheme. Results showed that grasslands of the region were under the pressure of the agriculture. Because, $67 \%$ of the most suitable regions were covered by the agricultural areas. However, $28 \%$ of the most suitable areas were covered by the grasslands (Table 5). In addition, agricultural areas were increased in last 15 years period, and main aspect of the LUC change was detected from grassland to the agriculture (Satir et al. 2016). 

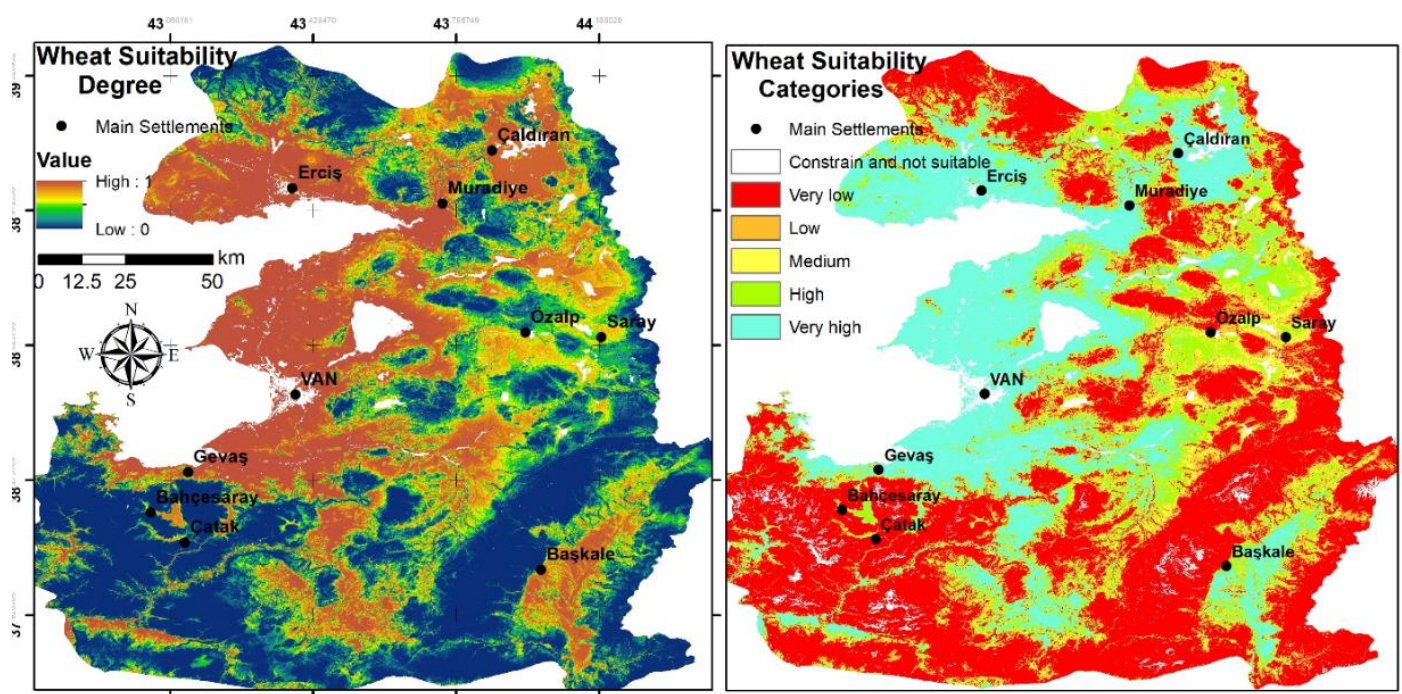

Figure 10. Wheat suitability maps by ANN approach.

Table 5. Areal analyses of the wheat suitability categories and distribution of the very high suitable areas based on current LUC

\begin{tabular}{|c|c|c|c|c|c|}
\hline Suitability & $(\%)$ Coverage & Area (ha) & LUC & $(\%)$ Coverage & Area (ha) \\
\hline Very high & 15 & 271220 & Agriculture & 67 & 181651 \\
\hline High & 30 & 582967 & Grassland & 28 & 76073 \\
\hline Medium & 31 & 593026 & Bareground & 4 & 13098 \\
\hline Low & 17 & 330127 & Other & $<1$ & 398 \\
\hline Very low & 3 & 56855 & & & \\
\hline Constraints & 4 & 59037 & & & \\
\hline
\end{tabular}

\section{Discussion and Conclusions}

This paper demonstrated two spatial decision support approaches considering some of the important environmental factors to map the wheat growth suitability. Agricultural areas have been decreased as a result of industrial development particularly in Turkey. The status of study area is taken as governmental subventions for the animal husbandry and field crops especially for the cereal cultivation. Therefore, this region is under the urbanization pressure due to immigration from the rural areas (Satir and Erdogan, 2016). Research was focussed on the wheat areas, also the wheat is one of the most resistant field crops in cold regions, and it is cultivated in large fields in the Eastern Turkey. Additionally, in the 2017-18 marketing year (July/June), cereal imports were increased to 7.4 million tonnes (up 4 percent) compared to previous year that was the 7.1 million tonnes particularly in wheat (FAO, 2018). Although the wheat cultivation and yield have been increased, wheat import has been in an increasing trend. However, production increase was caused by the ideal climatic conditions instead of the increase in wheat fields (USDA, 2018). Therefore, crop based protection on agricultural land management must be one of the most important priority in Turkey and fast developing countries. As a result of the priority analysis, precipitation is an important factor because cereal production is only dependent on rainfall or snow melts in the study area.

Ideal data based approaches were applied, and wheat cultivated fields were used to be ideal places covering two years growing periods in the study area. Many similar studies on agricultural suitability mapping were used expert based or literature based techniques to define priority of factors and AHP approach was used to define the weights of factors. Additionally, these studies ignored validation (Sarkar et al. 2014; Yalew et al. 2016). Therefore, this study bridges the gap between mapping and validating the crop growth suitability to get the more solid results. In this extent, two approaches were examined to be ideal data based linear and ANN. In the first approach, location of the existed wheat fields was analysed according to the spatial distribution inside the categories. So that factor importance was tried to detect for wheat growth based on hypotheses that was described in weighting section. In ANN technique, network architecture was established according to the input dataset and 
experimental analyses. Results of the two techniques were validated using ROC statistic and ROC coefficiencies were obtained to be 0.875 and 0.71 respectively. Linear technique was more successful than ANN in our study. In linear approach, weighting of the input factors was completed using standard deviation based method and this method was in user control, so user can be modified the categorization thresholds. However, in ANN technique weights were defined automatically according to the input parameters and training dataset. Additionally, distribution of the training points in each category was considered in linear technique. Başkale location (South Eastern) was more suitable than linear technique for wheat cultivation in ANN technique. Training point density was less than other regions in this part because only some limited areas have been suitable for agriculture in Başkale region and linear technique was defined successfully. On the other hand, ANN method was defined Başkale region as very high suitable for wheat cultivation. In general, this region is suitable for wheat farming, but productivity is less than lakesides.

In conclusion, suitable regions were located around the Van Lake because of appropriate climatic and topographic conditions. Combination of the ideal data and multiple data assessment technique in a GIS environment has an impressive potential to evaluate the crop growth suitability. In this extent, cultivated parcels or yield dataset can be used to extract the ideal parcels or points for the crop growth. Transportation accessibility, hill shade (sun effect), slope and precipitation were defined the most significant factors on wheat growth in the study area orderly. Another result of the study was that only the $67 \%$ of the very suitable classified areas were agriculture today. It is mean that there are some very suitable fields which has not been used for agriculture in the region. This result is important for the land use planners to calculate potential ecosystem service value, and livestock in the region.

\section{Acknowledgement}

We authors would like to say thanks to the Van Provincial Directorate of Agriculture to share the cultivated wheat field data for this research.

\section{References}

Arnell, N. W. (1999). Climate Change and Global Water Resources. Global Environ. Change, 9, 31 49.

Barton, M. H., Buchberger, S. G., Lange, M. J. (1999). Estimation of error and compliance in surveys by kriging. J. Surv. Eng, 125, 87-108.

Bilgic, H., Hakki, E. E., Pandey, A., Khan, M. K., Akkaya, M. S. (2016). Ancient DNA from 8400 YearOld Çatalhöyük Wheat: Implications for the Origin of Neolithic Agriculture. PLoS ONE, 11(3), e0151974.

Bunruamkaew, K., Murayama, Y. (2011). Site suitability evaluation for ecotourism using GIS\&AHP: A case study of Surat Thani province, Thailand. Proced. Social and Behavioral Sci, 21, 269278.

FAO. (2002). Food and Agriculture Organization of the United Nations, World Agriculture: towards 2015 - 2030 summary report. Rome.

FAO. (2018). Food and Agriculture Organization of UN, Global Information and Early Warning System (GIEWS) country briefs of Turkey.

Kalogirou, S. (2002). Expert systems and GIS: an application of land suitability evaluation. Computers Environment and Urban Syst, 26, $89-112$.

Kan, M., Küçükçongar, M., Keser, M., Morgounov, A., Muminjanov, H., Özdemir, F., Qualset, C. (2015). Wheat Landraces in Farmers' Fields in Turkey: National Survey, Collection, and Conservation, 2009-2014. Food and Agriculture Organization of the United Nations, Ankara. ISBN: 978-92-5-109048-0.

Karagöz, A., Pilanalı, N., Polat, T. (2006). Agro-Morphological Characterization of Some Wild Wheat (Aegilops L. and Triticum L.) Species. Turkish Journal of Agriculture and Forestry, 30, 387 398.

Kavzoglu, T., Sahin, E. K., Colkesen, I. (2014). Landslide susceptibility mapping using GIS-based multi-criteria decision analysis, support vector machines, and logistic regression. Landslides, $11,425-439$. 
Malczewski, J. (2007). GIS-based multicriteria decision analysis: a survey of the literature. Int. J. of Geog. Inf. Sci, 20(7), $703-726$.

Mosadeghi, R., Warnken, J., Tomlinson, R., Mirfenderesk, H. (2015). Comparison of fuzzy-AHP and AHP in spatial multi-criteria decision making model for urban land-use planning. Computers Environment and Urban Syst, 49, 54-65.

Parry, M., Rosenzweig, C., Iglesias, A., Fisher, G., Livermore, M. (1999). Climate Change and World Food Security: A New Assessments. Global Enviromental Change, 9, 51 - 67.

Rumelhart, D E, Hinton, G. E, Williams, R. J. (1986). Learning internal representations by error propagation. In: Rumelhart DE, McClelland JL, editors. Parallel distributed processing: explorations in the microstructure of cognition, volume 1: foundations. Cambridge, MA: The MIT Press, 318-362.

Saaty, T. (1980). The Analytical Hierarchy Process. New York: John Wiley.

Saaty, T. (2008). Relative measurement and its generalization in decision making: why pairwise comparisons are central in mathematics for the measurement of intangible factors e the analytic hierarchy/network process. Review of the Royal Spanish Aca. of Sci. Series A Math, 102(2), 251-318.

Sarkar, A., Ghosh, A., Banik, P. (2014). Multi-criteria land evaluation for suitability analysis of wheat: a case study of a watershed in eastern plateau region, India. Geospatial Inf. Sci, 17(2), 119-128.

Satir, O., Berberoglu, S., Donmez, C. (2016). Mapping regional forest fire probability using artificial neural network model in a Mediterranean forest ecosystem. Geomat. Nat. Hazards and Risk, 7(5), 1645-1658.

Satir, O., Berberoglu, S. (2016). Crop yield prediction under soil salinity using satellite derived vegetation indices. Field Crops Research, 192, 134-143.

Satir, O., Erdogan, M.A. (2016). Monitoring the land use/cover changes and habitat quality using Landsat dataset and landscape metrics under the immigration effect in subalpine eastern Turkey. Environ Earth Sci, 75, 1118.

Şatır, O. (2013). Determining the agricultural land use suitability using remote sensing and geographical information system in Lower Seyhan Plane. In: PhD Thesis. Cukurova University Natural and Applied Sciences Ins, Adana, Turkey.

Şatir, O. (2016). Mapping the Land-Use Suitability for Urban Sprawl Using Remote Sensing and GIS Under Different Scenarios, in: Ergen, M. (Ed.), Sustainable Urbanization. INTECH, London, pp. $205-226$.

Şatır, O., Alp, Ş., Bostan, P., Baylan, E., Yeler, O., Aşur, F. (2017). Periodic land use cover change detection in Van Lake Basin in half century. Yuzucunu Yil University scientific research office project final report, project number: 2014-ZF-B220, Van Turkey.

TSMS. (2015). Turkish state meteorological service database. 2006 - 2015 long term maximum, minimum and mean temperature, total annual precipitation and solar radiation datasets for Eastern Turkey.

TSI. (2013). Turkish Statistical Institute. Population records of the Turkey.

TSI. (2018). Turkish Statistical Institute. Crop production statistics for Van Province, Turkey.

TSI. (2020). Turkish Statistical Institute. Population records of the Van Province, Turkey.

UN. (2013). United Nations, Department of Economic and Social Affairs, Population Division, Population Estimates and Projections Section, World population prospects: the 2012 revision. http://esa.un.org/unpd/wpp/Excel-Data/population.htm. Accessed on: 05.04.2013.

USDA. (2018). United States Department of Agriculture Foreign Agricultural Service, reports of Grain: World markets and trade, https://apps.fas.usda.gov/psdonline/circulars/grain.pdf, Accesed on 20.07.2018.

WB (World Bank). (2013). World Bank data catalogue, agricultural land (\% of land area). http://data.worldbank.org/indicator/AG.LND.AGRI.ZS/. Accessed on: 05.04.2013.

Yalew, S. G., Griensven, A., Mul, M. L., Zaag, P. (2016). Land suitability analysis for agriculture in the Abbay basin using remote sensing, GIS and AHP techniques. Model Earth Syst. Environ, 2, 101. 